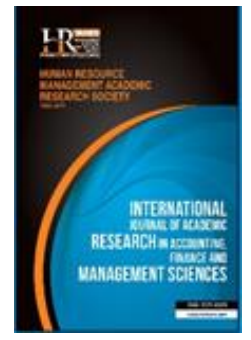

International Journal of Academic Research in Accounting, Finance and Management Sciences

Vol. 9, No.1, January 2019, pp. 94-104

E-ISSN: 2225-8329, P-ISSN: 2308-0337

(C) 2018 HRMARS

www.hrmars.com

To cite this article: Jusaj, Y. (2019). Kosovo Oil Industry and Excise Tax Impact, International Journal of Academic Research in Accounting, Finance and Management Sciences 9 (1): 94-104.

http://dx.doi.org/10.6007/IJARAFMS/v9-i1/5775 (DOI: 10.6007/IJARAFMS/v9-i1/5775)

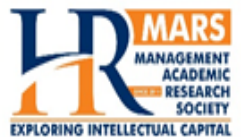

\title{
Kosovo Oil Industry and Excise Tax Impact
}

\section{Yvesa Jusaj}

South East European University, Macedonia, E-mail: yvesajusaj@gmail.com

\begin{abstract}
This research project present the current condition of the Kosovo oil market and identifies the main complicating factors that causes difficulties for domestic companies to operate nationally and internationally. Detailed analysis and comparisons are accomplished regarding the contemporary situation of fuel market in Kosovo, European nations and America with the focus being on the fuel excise tax. The discussion continues further relating to domestic oil production and exports versus imports of petroleum products. The focus was set as well in key drivers of the market size, level of competition, consumer complaints and government, and regulatory policy. The project needed to be as accurate as possible by representing current conditions in a very clearly way; therefore beside literature review, a structured questionnaire was prepared for consumers. This was intertwined with the aim to figure out whether companies are acting accordingly with consumers' needs and wants. Consequently, all of the results are discussed and analyzed with the goal to comprehend what they mean to the project- by considering limitations and their impact on the project as well. To complete the project, a conclusion with recommendations was provided, the one, which is very useful in developing more favorable conditions in the fuel market.

Key words

Consumer Complaints, Excise Tax, Kosovo Oil Market, Policies, Petroleum

\begin{tabular}{|c|c|c|}
\hline Received: & 20 Apr 2019 & (C) The Authors 2018 \\
\hline Revised: & 01 May 2019 & Published by Human Resource Management Academic Research Society (www.hrmars.com) \\
\hline $\begin{array}{l}\text { Accepted: } \\
\text { Published Online: }\end{array}$ & $\begin{array}{l}12 \text { May } 2019 \\
21 \text { May } 2019\end{array}$ & $\begin{array}{l}\text { This article is published under the Creative Commons Attribution (CC BY } 4.0 \text { ) license. Anyone may } \\
\text { reproduce, distribute, translate and create derivative works of this article (for both commercial and } \\
\text { non-commercial purposes), subject to full attribution to the original publication and authors. The full } \\
\text { terms of this license may be seen at: http://creativecommons.org/licences/by/4.0/legalcode }\end{array}$ \\
\hline
\end{tabular}
\end{abstract}

\section{Introduction}

Kosovo being as one of the youngest countries in Europe and in twisted circumstances among regions, it is still rebuilding its economic progress. The war history let Kosovo struggling with economy even after eleven years of independence. Considering damages and the situation, which has taken place since the war of late 90's, it pointed out that Kosovo, need to make new investments especially in economic sectors? In order to upsurge new investments, it needs to attract both domestic and international investors. However, one of the main economic problems among others is the current complex situation being present in the oil market with the focus being in the high fuel excise tax. Of course, that fuel prices differ based on pump, location and region, however, prices are determined by international stock market. That is why oil prices differ when comparing countries. Even despite the worldwide plunging, Kosovo continues to have one of the highest oil prices when comparing with other foreign fuel markets. The main concern is that Kosovars companies make the same prices change as the prices rise internationally but when prices drop globally, companies do not make the same drop. According to Kosovar experts of economic affairs, "when the price in the world increases, our petrol stations are very attentive to increase it, but when prices go down by $50 \%$ in the world, our petrol stations reduce them only by 16\%"(Independent Balkan Agency, 2015). By this, economic experts describes that one of the reasons why oil companies operate in this manner is because of that 0.35 cent excise tax they pay per liter of oil (diesel) 
and 0.38 cent for gasoline. Actually, this value is quite high when comparing with the amount of what other regions pay. The unavailability to reduce prices is what raises consumer concerns and let transportation companies to complain for the actual situation they are being faced with.

\subsection{Background Information to Problem}

Among all other existing industries, fuel is one of the fastest growing industrial sector in the current global market. This situation takes place in Kosovo as well since the significant increase in the number of petroleum companies. Most of the known companies in the country are those large ones, which import fuel derivatives from various countries of the region; mainly from European nations. While the smaller companies because of the unavailability importing from foreign countries, the domestic large ones supply them. Since 2009, with the enforcement of law no.2004/5 on Trade with Petroleum and Petroleum Products, companies started to operate more freely in the market. This law applies to the wholesale and retail supply transport, and storage of petroleum and all petroleum products (Statement of Security of Supply for Kosovo, 2015). Kosovo do not have the capacity of neither oil production nor oil exports. Actually, Kosovo is net importer of petroleum products and produces only heavy fuel oil for heating. Such production is achieved with the help of imported raw material amounting $1 / 4$ of the heavy fuel oil consumption. Since Kosovo has insignificant amounts of export, most of the production within the country is covered by imports (Statement of Security of Supply for Kosovo, 2015). In fact, Kosovo is very dependent on imports of fuel derivatives. Long time ago, Kosovo imported only from Albania, Bosnia \& Herzegovina, Serbia, Greece and Montenegro. While now, Kosovo developed even more its economic relations with neighboring states and in terms of oil trade is being more familiar since expanding its affairs further with other European nations (Statement of Security of Supply for Kosovo, 2015). Since oil prices are determined from the international stock markets, every change that happens to international countries will also affect the Kosovar oil market. The fuel prices in the international market are considered the lowest one, especially during the past four years. Nevertheless, even that prices has fallen internationally, Kosovo continues with the highest petroleum prices among most of the regions. Since the list of countries is huge, below in the tables are represented only the five world cheapest countries for petrol.

Table 1. Cheapest Global Petrol Prices

\begin{tabular}{|c|c|c|}
\hline No & Country & $\begin{array}{c}\text { Gasoline Prices } \\
\text { (liter, U.S Dollar) }\end{array}$ \\
\hline 1 & Venezuela & 0.01 \\
\hline & & \\
\hline 2 & Sudan & 0.13 \\
\hline 3 & Iran & 0.29 \\
\hline 4 & Kuwait & 0.34 \\
\hline 5 & Algeria & 0.35 \\
\hline
\end{tabular}

\begin{tabular}{|c|c|c|}
\hline No & Country & $\begin{array}{c}\text { Diesel Prices } \\
\text { (liter, U.S Dollar) }\end{array}$ \\
\hline 1 & Venezuela & 0.00 \\
\hline 2 & Iran & 0.07 \\
\hline 3 & Sudan & 0.09 \\
\hline 4 & Saudi Arabia & 0.13 \\
\hline 5 & Algeria & 0.19 \\
\hline
\end{tabular}

Source: Global Petrol Prices, 2019.

As it seems on the tables, in the global petroleum market, the price per liter is significantly low. Nevertheless, such occurrence does not seem to transpire in Kosovo. Based on data recorded on March 2019, Kosovo have fuel prices starting from 0.99€ to 1.07€ (Fuel Prices Europe List, 2019). Even when taking into account the fuel excise tax among regions, again Kosovo has one of the highest fuel excise tax. "The government of Kosovo is interested to have high prices because it charges $0.35-0.38$ cent per liter in excise - plus 16\% VAT" (Tota, 2017). By this, representatives of oilmen claim that are institutions those that must license more subjects or regulate the market. Moreover, they claim that, "It's absurd for Kosovar oil companies to pay excise amounting to the price of a liter (today, the price of a liter of oil in the international market is 0.34 Euros). Diesel is not a luxury product, but a basic product for every other product produced in Kosovo" (Tota, 2017). That is, representatives of oilmen also complain that is unaffordable for them to pay such excise amount. However, Kosovo deals with such problems since long time ago and the same situation still prevails even today. 


\subsection{Objectives of the study}

Petroleum products have both direct and indirect role on the domestic economy because of their prices affecting the health of the economy as a whole. Petroleum products are incredibly important not only to individuals, but to businesses as well. Because of their inevitable usage, citizens and companies spend different financial amounts toward those products. What takes the attention is that high prices have become a serious concern for Kosovar citizens. Therefore, the objectives of this research paper are to:

-Identify the level of citizens' dissatisfaction toward petroleum products

- Identify the main factors increasing the petroleum product prices

- Provide recommendations to Kosovar oil companies how to overcome the challenges and minimize deficiencies based on the results of the research.

\subsection{Research Questions and Hypothesis}

The research project will try to give answers to the following research questions:

1. At what level does excise tax affect the petroleum prices?

2. How does the fuel prices influence consumer' satisfaction toward buying the petroleum products?

3. What policies and regulations should implement to create a better and comfortable environment in this industry?

In addition, as the hypotheses that this paper will test will be:

H1: Despite other expenses, excise tax is the main concern factor affecting the price of petroleum products

H2: Petroleum prices are unaffordable when considering what economic level and unemployment rate the country faces with

H3: Customers are partly satisfied with fuel quality and service

\section{Literature review}

\subsection{Agreement between OPEC Members Affect the Kosovar Fuel Market}

The $19^{\text {th }}$ century is considered to be the period of great change and rapid industrialization. There was a huge extension in iron and steel industry; moreover the railroads connected countries with each other and discover of oil provided a new source of fuel. Because of the huge extension of the fuel industry, the intergovernmental organization known as OPEC (The Organization of the Petroleum Exporting Countries) is trying to coordinate oil production policies by creating price and market stabilization and maintain stability in oil production. This cartel charter is composed of thirteen states such as Kuwait, Venezuela, Iran, Iraq, Saudi Arabia, Algeria, Libya, Nigeria, Ecuador, Gabon, Angola, United Arab Emirates, and Qatar. These thirteen countries produce $40 \%$ of the crude oil, thus, any agreement made by them will affect the entire world. When OPEC started functioning, oil prices were quite high but after a long period they started to decline. The sharp drop in oil prices was recorded in 2014 (OPEC's Dominance of the Global Oil Market, 2004). Economists have introduced four factors that brought to such sharp drops such as:

1. The US dollar experienced a huge surge in value;

2. The inability of OPEC to reach an agreement regarding the amount of oil produced;

3. The inability to regulate the supply of oil;

4. The overall decrease in demand for oil.

After two years of such sharp decline, in 2016 OPEC members achieved an agreement that in order to increase the fuel prices, the fuel production must be cut (Focus Economics, 2017). Such agreement included also other non-OPEC members such as Russia agreeing to cut production. While in the other hand, Norway was the only state refusing the deal. Because of approving the pact, Russia as a non-OPEC producer cut 600,000 barrels per day, by reducing its output by 300,000 daily barrels. However, how does this agreement affect the Kosovar fuel market? Among primary imports in Kosovo, oil is ranked in the third place after food and cigarettes. Normally, as the price of oil increases, the cost of importing it will increase undoubtedly. Because of that agreement, oil prices in Kosovo experiences an upsurge (RIT Kosovo Economists' Club, 2016). 


\subsection{Main Factors that Affect Kosovar Oil Prices}

The two main sources of fuel in the modern life and transportation are diesel and gasoline. Because of their huge worldwide demand, any change made on their prices is immediately made a public issue. The extreme fluctuations of fuel prices is what has directly affected diesel and gasoline retail prices globally in most of the Western countries by raising public concerns about the pricing behaviors of fuel companies. Considering the fact that oil is the most consumed energy, it has a direct role in the daily lives and as well in the social and economic progress. However, prices differ and change because of several factors within region. Based on a recent study, "Most Europeans pay a much greater price for gasoline than Americans do, anywhere between $\$ 6$ and $\$ 10$ per gallon" (Mahapatra, 2019). Are such "price differences" what affect the oil industry, and raise the consumer question of "why does prices rise and fall very repeatedly". Actually, in Kosovar fuel market several factors have a direct impact on price fluctuations such as fundamental factors (economic growth, OPEC production capacity, policy of OPEC, oil reserves and alternative energy), sentimental factors, technical factors and miscellaneous factors (foreign exchange). Because of the broad scope of explaining all of the factors, the technical factors will not be introduced here.

\subsubsection{Fundamental Factors}

The primary focus for the price determination is set on the supply and demand side of fuel. Of course that price determination is influenced by different factors but the imbalance between the supply and demand is what affects it mostly. The factors included in "imbalance between supply and demand" are the following;

I. Economic Growth - it has a positive correlation with the price of oil. When the economy grows, the oil demand increases but the inability of world production to meet the demand growth leads to price increases. Contrary, if economic growth is insignificant, then prices will decrease as the result of oversupply of oil. Kosovo economy has shown progress in maintaining an economic stability but still being dependent in international community. Kosovo been highly dependent in imports of oil products, in 2014 it imported petroleum products only from five countries while after 2014 continued to expand its market by importing from more than eight European nations (Statement of Security of Supply for Kosovo, 2015).

II. OPEC production capacity - most of the worldwide oil producers are OPEC members who directly can control and manage production to meet consumption. That is why the level of production affects directly the price determination. One of similar cases is the agreement made between OPEC and Russia. Because of their agreement, Kosovo oil prices increased to $1.08 €$ per barrel.

III. Policy of OPEC - as the world's largest reserves and producer, OPEC member's announcement to cut or increase the production level, unavoidably triggers the oil price. Such actions affect the worldwide oil price market. Even that Kosovo is not directly influenced by the OPEC actions, still at some level it is impacted by its members' decisions.

IV. Oil reserves and alternative energy - in Kosovar market, law on trade with petroleum and petroleum products obliges "all petroleum and petroleum products storage facilities and sale points to maintain reserves of at least $5 \%$ of their storage capacity at any time for emergency purposes"(Statement of Security of Supply for Kosovo, 2015). Storage capacities have around 80,000 m3 and 40,000 m3 for fuel retail sales ( $5 \%$ of this capacity is equals to 4 days average daily import). While in the other hand, there are exactly $50,000 \mathrm{~m} 3$ of storages capacities being not being used or licensed for fuel storages. In total, there are 12 storage facilities licensed for fuel wholesale. In order to continue meeting the necessary requirements of law on trade, Kosovo should continue import and maintain the needed oil reserves (Statement of Security of Supply for Kosovo, 2015).

\subsubsection{Sentimental Factors}

Political and economic movements in any region directly or indirectly affect the word oil prices. Based on Kosovo Oilmen Association, Kosovo deals with one of the highest fuel prices among other countries by having also one of the uppermost fuel excise tax. Actually, Kosovo continues to have the highest fuel excise tax for imports of petroleum products. According to Kosovar economic experts, for just 1 
year in our country, oil imports have approximately 600 million euros, specifying that the oil sector pay state taxes of about 300million euros (Kosovo - Import Tariffs, 2019).

\subsubsection{Miscellaneous Factor}

Foreign Exchange - since oil is traded internationally and sold in US dollar, as a result, any change of other currencies when comparing with the US dollar will affect the price of oil. When us dollar diminishes, the price of imported petroleum products will be cheap when calculated in local currency. Contrariwise, the price would be higher. As strong the US dollar is, the lower oil price would be. Actually, European nations make price changes by using the "Euro System" which represents those "price changes" that all European fuel companies use when setting their fuel prices. Between those countries is found Kosovo as well which use the same system of price set too.

\subsection{Domestic Production and Exports versus Imports of Petroleum Products}

Kosovo production capacity and exports were nonexistent immediately after the war in 1999. After the privatization process of some of the main factories such as Ferronickel, both export and domestic production eventually emerged at a very low level. In 2017, the GDP in Kosovo was 7.13 billion US dollars and such value represents only 0.01 percent of the whole world economy (Kosovo GDP, 2019). However, GDP composition by the sector is as the following;

- agriculture: $12.9 \%$

- industry: $22.6 \%$

- services: $64.5 \%$

Based on this composition, exports remain in low levels as share of GDP, approximately less than $6 \%$ of the GDP. One of the biggest increases was the one recorded on the period 2005-2008- rising from $€ 56$ million to $€ 199$ million. As declared by KAS, in 2018 exports of goods were 29.4 million euros, while imports reached 302.9 million euros (Kosovo Agency of Statistics, 2019). Actually Kosovo doesn't have the capacity of exporting petroleum but for more details lets refer to the below table 2 .

Table 2. Oil and Gas Production/Consumption

\begin{tabular}{|l|c|c|c|c|}
\hline \multicolumn{1}{|c|}{ Country } & $\begin{array}{c}\text { Oil Production } \\
(\mathrm{bbl} / \mathrm{d})\end{array}$ & $\begin{array}{c}\text { Oil Consumption } \\
(\mathrm{bbl} / \mathrm{d})\end{array}$ & $\begin{array}{c}\text { Gas Production } \\
(\mathrm{bbl} / \mathrm{d})\end{array}$ & $\begin{array}{c}\text { Gas Consumption } \\
(\mathrm{bbl} / \mathrm{d})\end{array}$ \\
\hline Albania & 21,100 & 24,000 & 0,00 & 0,00 \\
\hline Bosnia \& Herzegovina & 0,00 & 33,000 & 0,00 & 0,25 \\
\hline Bulgaria & 3,600 & 90,000 & 0,20 & 2,65 \\
\hline Croatia & 18,000 & 76,000 & 1,52 & 2,50 \\
\hline Cyprus & 0,00 & 53,000 & 0,00 & 0,00 \\
\hline FYROM & 0,00 & 18,000 & 0,00 & 0,15 \\
\hline Greece & 1,900 & 285,300 & 0,00 & 2,70 \\
\hline Montenegro & 0,00 & 6,100 & 0,00 & 0,00 \\
\hline Romania & 103,000 & 187,200 & 9,7 & 10,5 \\
\hline Serbia & 20,560 & 76,000 & 0,50 & 2,70 \\
\hline Kosovo & $\mathbf{0 , 0 0}$ & $\mathbf{1 2 , 0 0 0}$ & $\mathbf{0 , 0 0}$ & $\mathbf{0 , 0 0}$ \\
\hline Turkey & 61,000 & $\mathbf{7 1 9 , 2 7 0}$ & 0,50 & 44,7 \\
\hline \multicolumn{1}{|c|}{ Total } & $\mathbf{2 2 9 , 1 6 0}$ & $\mathbf{1 , 5 7 9 , 8 7 0}$ & $\mathbf{1 2 , 4 2}$ & $\mathbf{6 6 , 1 5}$ \\
\hline
\end{tabular}

Source: IENE study “South East Europe Energy Outlook 2016/2017", Athens, 2017

When comparing with other nations, Kosovo differ from all other countries because the value 0.00 being recorded in both oil and gas production. This means that Kosovo does not produce oil and gas products. In fact, there are two licensed production plants: Kosovo A and Kosovo B, which currently produce fuel oil mainly, used for heating. One of them used to produce diesel but it stopped the production in 2012. In 2012, both of the plants supplied around 11.1 tons of fuel oil to domestic market. Such production was covered by imports of raw materials from other countries such as gasoil, kerosene and heavy fuel oil. Because of the unavailability of domestic oil production, Kosovo is entirely dependent in imports of petroleum products from other states. 


\subsection{Key drivers of the market size}

The key drivers of the market size are the volumes of the fuel sold which includes the following factors such as;

- The total number of vehicles

- The fuel type

Starting with the total number of vehicles, there was an increase for each year in the number of cars being registered. This can be seen as well in the below table when the car registration starts from 2011 and end with the last recorded statistics in 2017.

Table 3. Motor and Non-motor Vehicles Registration

\begin{tabular}{|l|c|c|c|c|c|c|c|}
\hline \multicolumn{1}{|c|}{ Year } & $\mathbf{2 0 1 1}$ & $\mathbf{2 0 1 2}$ & $\mathbf{2 0 1 3}$ & $\mathbf{2 0 1 4}$ & $\mathbf{2 0 1 5}$ & $\mathbf{2 0 1 6}$ & $\mathbf{2 0 1 7}$ \\
\hline Vehicles & 170.321 & 176.398 & 222.537 & 236.145 & 281.847 & 260.291 & 273.862 \\
\hline Transport vehicles 3.5 and <3.5 ton & 10.877 & 11.547 & 15.352 & 15.769 & 18.330 & 17.963 & 18.559 \\
\hline Transport vehicles under 3.5 ton & 17.901 & 18.225 & 24.659 & 26.949 & 30.846 & 31.285 & 32.299 \\
\hline Minivans & 2.698 & 2.520 & 3.225 & 3.161 & 3.212 & 2.841 & 2.535 \\
\hline Buses & 1.117 & 1.298 & 1.570 & 1.697 & 2.124 & 1.916 & 1.949 \\
\hline Motorcycles & 546 & 809 & 1.488 & 1.540 & 1.849 & 1.790 & 1.690 \\
\hline Tractors & 39 & 137 & 776 & 1.036 & 941 & 613 & 523 \\
\hline Trailer under 3.5 ton & 101 & 117 & 217 & 250 & 286 & 288 & 288 \\
\hline Trailer 3.5 and <3.5 ton & 1.766 & 1.800 & 2.283 & 2.281 & 2.707 & 2.628 & 2.735 \\
\hline \multicolumn{1}{|c|}{ Total } & $\mathbf{2 0 5 . 3 6 6}$ & $\mathbf{2 1 2 . 8 5 1}$ & $\mathbf{2 7 2 . 1 0 7}$ & $\mathbf{2 8 8 . 8 2 8}$ & $\mathbf{3 4 2 . 1 4 2}$ & $\mathbf{3 1 9 . 6 1 5}$ & $\mathbf{3 3 4 . 4 4 0}$ \\
\hline
\end{tabular}

Source: Ministry of Internal Affairs

As it can be noticed on the table, in 2017 in Kosovo were registered about 334.440 motor and nonmotor vehicles or 14.825 vehicles more than in 2016. Such increase came as a result that most of the households correspond more than one car. The fuel type is another important factor driving the total volumes of retail fuels in the market. The increase of cars being present in the country has caused dramatic increases on fuel consumption. But there must be made a distinction between old e new cars imported in the country and by how much they consume oil derivatives. There was an increase in the number of both imported old and new cars in Kosovo. But when analyzing the percentage of cars being imported by their age, it is clearly seemed that old cars are less imported than new ones (Kosovo Agency of Statistics, 2018). However, considering it in general terms, such increase in the import of cars of different ages brought an increase in the fuel consumption as well.

\section{Methodology of research}

Project included both primary and secondary data. Beside the literature review done online, there was prepared a questionnaire for consumers. Actually, before starting to conduct the research, the aim of the project was to be implemented in the most well-organized and representative way while minimize possible problems. Hence, the focus was to tackle down the issue such as content concerns, population issues, administrative issues, bias issues and survey questionnaires format.

\subsection{Participants}

Research project included 3725 members asked by survey.

\subsection{Apparatus and material}

In order to create the survey questionnaire, the usage of computer programs was needed. Despite the physical share, the questionnaire was developed through the online system too. The system enabled the share of survey through online social networks. Beside these, other program such as Excel and Word was also necessary when introducing and analyzing the survey results by collocating data.

\subsection{Procedure}

The project included both qualitative and quantitative research methods. Since lot of available online information, the research was conducted only in one specific way - the survey. There was prepared a 
questionnaire for consumer to be answered and all of participants joined it in the best voluntarily way. The survey contained 10 questions with the aim to target consumers' thoughts and their preferences regarding the topic. The questionnaire was shared through physical and online means with the main intention to let people think and pay more attention while answering the questions. The first reason of using the online system was to generate faster responses while the second one is that people feel more comfortable to fill up survey in their phones/computers rather than stop in the streets where conditions may be unfavorable to complete and fully understand the questionnaire. Nine of the ten questions were designed in both multiple choices and check box structure because it requires less time speeding in fulfilling them. "Fill in questions" design was not used because it requires more time and most of the cases they are blank because participants may need more time to spend on them. While only one question was to "rank the options". However, they were asked to fill up the survey individually rather than in groups since group work may influence each other answers. All participants were provided with all necessary instructions before they took the survey in order to avoid misunderstandings and at the same time let them be aware about the project they are participating in.

\section{Data presentation and analyses}

Table 4 represents the demographic characteristics of participants included in the survey such as gender and age.

Table 4. Demographic characteristics of participants

Table 5. Family yearly income

\begin{tabular}{|c|c|c|c|}
\hline \multicolumn{3}{|c|}{ Descriptive Statistics } \\
\hline \multirow{3}{*}{ Gender } & Male & Frequency & Percent \\
\cline { 2 - 4 } & Female & 12456 & 66 \\
\hline \multirow{6}{*}{ Age } & $18-24$ & 766 & 34 \\
\cline { 2 - 4 } & $25-34$ & 1346 & 21 \\
\cline { 2 - 4 } & $35-44$ & 665 & 36 \\
\cline { 2 - 4 } & $45-49$ & 437 & 18 \\
\cline { 2 - 4 } & $50-54$ & 324 & 12 \\
\cline { 2 - 4 } & $55-64$ & 174 & 9 \\
\cline { 2 - 4 } & $>65$ & 13 & 0 \\
\hline
\end{tabular}

\begin{tabular}{|l|l|c|c|}
\hline \multirow{4}{*}{ Valid } & & Frequency & Percent \\
\cline { 2 - 4 } & $<10,000 €$ & 2334 & 63 \\
\cline { 2 - 4 } & $10,000-20,000 €$ & 789 & 21 \\
\cline { 2 - 4 } & $21,000-30,000 €$ & 221 & 6 \\
\cline { 2 - 4 } & $>31,000 €$ & 43 & 1 \\
\cline { 2 - 4 } & No answer & 338 & 9 \\
\cline { 2 - 4 } & Total & 3725 & 100 \\
\hline
\end{tabular}

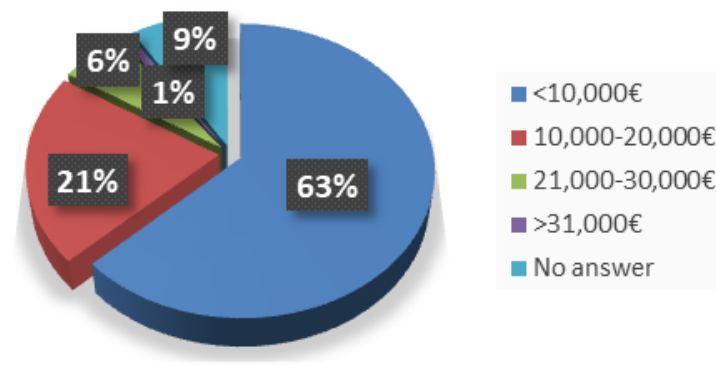

From the results obtained and presented in fig. 1 and the distribution of the respondents' responses, $63 \%$ of respondents declared that they have a family yearly income of $<10,000 €$ while $21 \%$ claimed that they have $10,000 €$ $20,000 €$ family yearly income. The rest of the respondents found themselves in the three other options as presents on the table.

Figure 1.

Table 6. Do you think oil prices are high?

\begin{tabular}{|l|l|l|l|}
\hline \multirow{4}{*}{ Valid } & & Frequency & Percent \\
\cline { 2 - 4 } & Very high & 700 & 19 \\
\cline { 2 - 4 } & High & 1234 & 33 \\
\cline { 2 - 4 } & Acceptable & 879 & 24 \\
\cline { 2 - 4 } & Low & 558 & 15 \\
\cline { 2 - 4 } & I don't know & 354 & 10 \\
\cline { 2 - 4 } & Total & 3725 & 100 \\
\hline
\end{tabular}

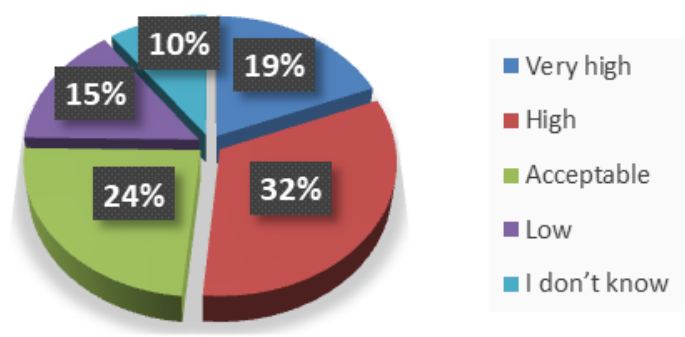

Figure 2. 
From the results obtained and presented in figure 2 and the distribution of the respondents' responses, around $19 \%$ of respondents argued that oil prices are very high, while $33 \%$ declared that prices are simply high. Approximately $24 \%$ of respondents claimed that prices are acceptable while $15 \%$ circled the option of low prices. Around 105 of respondents simply do not know or have a clear thought regarding to this question.

Table 7. If you think oil prices are too high, what is the reason for the high price?

\begin{tabular}{|c|c|c|c|}
\hline & & Frequency & Percent \\
\hline \multirow[t]{6}{*}{ Valid } & Oil excise & 1825 & 49 \\
\hline & $\begin{array}{l}\text { Oil prices are set by the } \\
\text { manufacturing companies } \\
\text { themselves }\end{array}$ & 572 & 15 \\
\hline & Demand and supply & 893 & 24 \\
\hline & $\begin{array}{l}\text { Prices are higher during the } \\
\text { summer season }\end{array}$ & 433 & 12 \\
\hline & $\begin{array}{lll}\text { Other reason } & \text { (please } \\
\text { specify) } & & \\
\end{array}$ & 2 & 0 \\
\hline & Total & 3725 & 100 \\
\hline
\end{tabular}

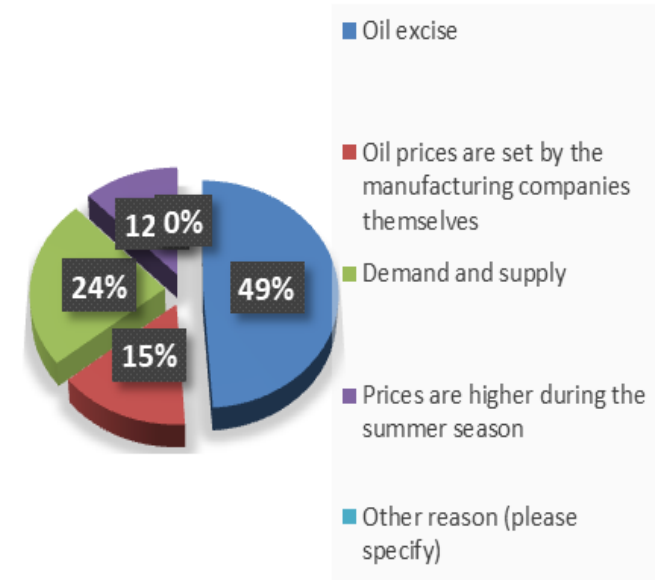

Figure 3.

From the results obtained and presented in fig. 3 and the distribution of the respondents' responses, $49 \%$ of respondents declared that the main factor for high prices of fuel is the oil excise tax while $15 \%$ argued that such high price of petroleum derivatives comes because the manufacturing companies themselves set the oil prices. Around $24 \%$ of respondents claimed about demand and supply while $12 \%$ selected the option that prices are higher during the summer season.

Table 8. Where do you usually buy fuel?

\begin{tabular}{|l|l|c|c|}
\hline & & Frequency & Percent \\
\hline Valid & Along the way home-work & 2345 & 63 \\
\cline { 2 - 4 } & $\begin{array}{l}\text { Along the way home-shopping } \\
\text { areas }\end{array}$ & 472 & 13 \\
\cline { 2 - 4 } & During the trips outside the city & 908 & 24 \\
\cline { 2 - 4 } & Other (please specify) & 0 & 0 \\
\cline { 2 - 4 } & Total & 3725 & 100 \\
\hline
\end{tabular}

Figure 4.

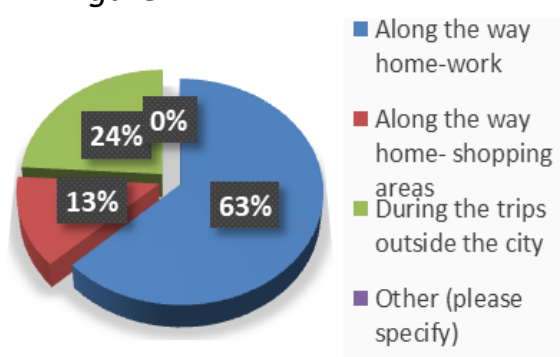

From the results obtained and presented in fig. 4 and the distribution of the respondents' responses, $63 \%$ of respondents claimed that they buy fuel along the way home - work, while $13 \%$ argued they buy fuel along the way home-shopping area. Approximately, $24 \%$ selected the option of during the trips outside of buying fuel.

Table 9. The oil station you mostly frequent is found near of:

\begin{tabular}{|c|c|c|c|}
\hline & & Frequency & Percent \\
\hline \multirow[t]{4}{*}{ Valid } & Your home & 2435 & 65 \\
\hline & Your work & 1076 & 29 \\
\hline & Other & 214 & 6 \\
\hline & Total & 3725 & 100 \\
\hline
\end{tabular}

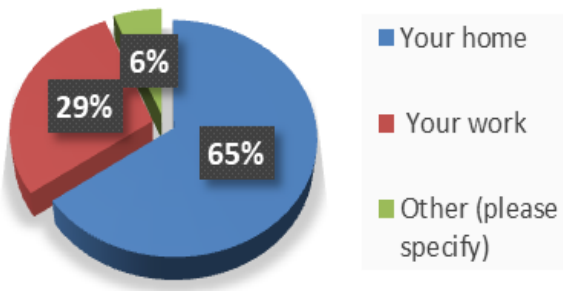

Figure 5.

From the results obtained and presented in fig. 5 and the distribution of the respondents' responses, $65 \%$ of respondents claimed that the oil station they mostly frequent is found near their home while $29 \%$ argued that they frequent the oil station located to their work. Approximately $6 \%$ of respondents declared that the oil station they frequent most often is located in areas different from the two first options. 
Table 10. What are the reasons that you frequent that oil station most often?

\begin{tabular}{|l|l|c|c|}
\hline & & Frequency & Percent \\
\hline Valid & Adequate location & 1012 & 27 \\
\cline { 2 - 4 } & Close to work & 673 & 18 \\
\cline { 2 - 4 } & Near the house & 831 & 22 \\
\cline { 2 - 4 } & $\begin{array}{l}\text { Close to the preferred } \\
\text { shopping area }\end{array}$ & 211 & 6 \\
\cline { 2 - 4 } & Lower prices & 85 & 2 \\
\cline { 2 - 4 } & Fast payment & 276 & 7 \\
\cline { 2 - 4 } & Fast and friendly service & 313 & 9 \\
\cline { 2 - 4 } & $\begin{array}{l}\text { Never problem with their } \\
\text { fuel derivatives }\end{array}$ & 324 & 8 \\
\cline { 2 - 4 } & Other (please specify) & 0 & 0 \\
\cline { 2 - 4 } & Total & 3725 & 100 \\
\hline
\end{tabular}

Figure 6.

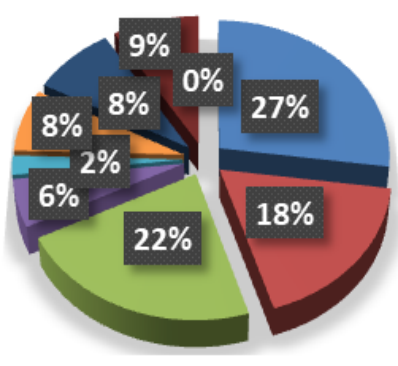

From the results obtained and presented in fig. 6 and the distribution of the respondents' responses, $27 \%$ of respondents declared that the main reasons for frequenting that oil station is because of the adequate location, while $18 \%$ of them claimed that they frequent that oil station because is close to work. Around $22 \%$ of respondents agreed about the "near the house" option while $6 \%$ chose the "close to the preferred shopping area" option. Approximately $2 \%$ of respondents visit their most frequent oil station because of lower prices while $7 \%$ because of the fast payment. Nevertheless, $9 \%$ of respondents claimed that the main detail for frequenting that oil station is because of the fast and friendly service while $8 \%$ do that because of they never had problems with fuel derivatives of that oil station.

Table 11. On average, how much your family spends on buying fuel monthly?

\begin{tabular}{|l|l|c|c|}
\hline \multirow{4}{*}{ Valid } & & Frequency & Percent \\
\cline { 2 - 4 } & $<25 €$ & 316 & 8 \\
\cline { 2 - 4 } & $25-50 €$ & 413 & 11 \\
\cline { 2 - 4 } & $50-75 €$ & 541 & 15 \\
\cline { 2 - 4 } & $75-100 €$ & 983 & 26 \\
\cline { 2 - 4 } & $>100$ & 1457 & 39 \\
\cline { 2 - 4 } & I don't know & 15 & 0 \\
\cline { 2 - 4 } & Total & 3725 & 100 \\
\hline
\end{tabular}

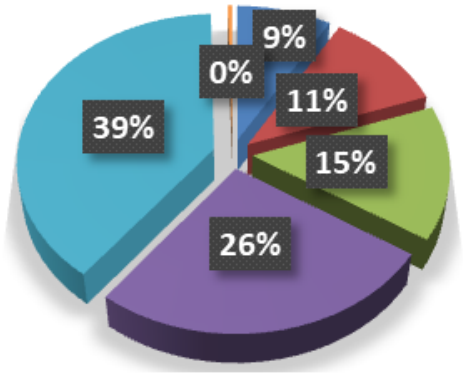

Figure 7.

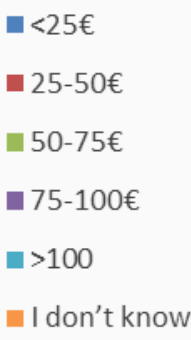

- I don't know

From the results obtained and presented in fig. 7 and the distribution of the respondents' responses, $8 \%$ of respondents claimed that their family spends $<25 €$ on buying fuel monthly, while $11 \%$ chose the option $20 €-25 €$ per month. Around $15 \%$ of respondents agreed that their family spends $50-75 \%$ monthly on buying fuel while $26 \%$ circled the option of $75 €-100 €$. Approximately, $39 \%$ of respondents declared that their family spends $>100 €$ monthly on buying fuel derivatives while $0 \%$ or 15 respondents from the total chose the option "I don't know" toward this question.

Table 12. Product/service quality satisfaction

\begin{tabular}{|l|l|c|c|}
\hline & & Frequency & Percent \\
\hline Valid & Very satisfied & 961 & 26 \\
\cline { 2 - 4 } & Somewhat satisfied & 1542 & 41 \\
\cline { 2 - 4 } & $\begin{array}{l}\text { Neither satisfied nor } \\
\text { dissatisfied }\end{array}$ & 612 & 16 \\
\cline { 2 - 4 } & Somewhat dissatisfied & 446 & 12 \\
\cline { 2 - 4 } & Very dissatisfied & 52 & 1 \\
\cline { 2 - 4 } & No answer & 112 & 3 \\
\cline { 2 - 4 } & Total & 3725 & 100 \\
\hline
\end{tabular}

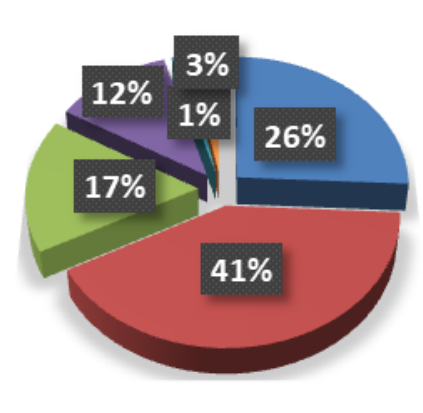

- Very satisfied

- Somewhat satisfied

Neither satisfied nor dissatisfied

- Somewhat dissatisfied - Very dissatisfied

No answer

Figure 8. 
From the results obtained and presented in fig. 8 and the distribution of the respondents' responses, $26 \%$ of respondents are very satisfied with product quality while $41 \%$ are somewhat satisfied with this statement. Around $16 \%$ of respondents are neither satisfied nor dissatisfied with quality of derivatives while $12 \%$ argued that they are very dissatisfied with this statement. Only $1 \%$ of respondents are very dissatisfied with this statement while $3 \%$ have no answer at all regarding to this question.

\section{Discussions and correlations}

As known, global transportation industry is one of the industries that have been growing at a significant pace since long time ago. The largest consumers of fuel are companies operating in the transportation industry. The demand for petroleum products has increased quite a lot and still it is expected to increase further in the next coming days. This is seen in the Kosovar oil market as well. As mentioned earlier, Kosovo had an increase in import of cars for each year by resulting in the increase of the consumption of petroleum products as well. This is what was collected in the survey as well. When comparing the unemployment rate and Kosovo economic level, even that consumers argue that oil prices are high as presented in the fig. 2 when around $33 \%$ of participants requested that prices are high, still because of the inevitable need, they spend huge amounts in consumption of oil derivatives. Most of the participants or $39 \%$ of them argued that they spends between $<100 €$ per month on buying fuel derivatives. Moreover, based on both literature review and secondary data, there are circumstances when consumers and experts of economic affairs agree and disagree with each other. As founded on secondary data, when experts and consumers were asked and interviewed about which is the main problem for such high prices and regular fluctuations, both of them primary set their own focus on the high fuel excise tax. As mentioned earlier, representatives of oilmen in Kosovo claim that oil companies deals with such prices because of the highest excise tax per liter. They claim that what complicates even more the situation is that except the high fuel excise tax, companies deal with other mandatory import spending such as transportation costs, acquisition cost, value added tax, etc. Figure 3 shows that when participants were asked about how serious the excise tax concern is, $49 \%$ of them claimed that such problem is very serious and in fact a big issue for high oil prices. Considering the fact that oil is the fastest growing industrial sectors in the current global market, Kosovo as well faced progress in such market. One of the reasons for the oil market expansion was the significant increase in the number of petroleum Kosovar companies. Nevertheless, the two key drivers of domestic oil company's expansion are location and competition. Actually, people have their favorite oil station when they purchase petroleum products on regular basis. What was founded from the survey responses, $65 \%$ of participants stated that they buy fuel derivatives in the way to home. When asked about what are some reasons this oil station is your favorite, $27 \%$ of participants claimed that they are regular consumer of their favorite oil station because of the appropriate location. As it can be realized so far, Kosovar oil market deals with both, its advantages and shortcomings. However, based on results of primary and secondary data, the aim of the project is to overcome the mentioned shortcoming by creating a better fuel market condition.

\section{Limitations}

Main limitations came from the secondary data, which in a way prevented the comprehensiveness of the project that would represent the whole society in a more precise way - a project serving as an example for other researchers. Actually, there were not enough information and available detailed analysis regarding Kosovar oil market. There was a lack of statistics, which were so necessary for the project and the only ones were those reported since long time ago from previous reports. Considering that were dramatics movements in the Kosovar oil market, there was no up-gradation on reports to have a more representative interpretation of the existing situation. Such limitations influence the applications to practice and the utility of findings that are the result of the method used to establish the validity of the topic.

\section{Conclusions and recommendations}

From the questionnaire realized with the competent people for this study in a hand, and from the secondary data gathered and completed in the adequate form in the other hand, the results substantiate the hypothesis mentioned in the beginning of the paper. What raises consumers complains are 
unaffordable high fuel prices. Based on collected results from primary and secondary data, one of the preclusive factors for reducing oil prices in the Kosovar fuel market is the high fuel excise tax that oil companies pay. Specifically, petroleum prices are unaffordable when considering what economic level and unemployment rate the country faces with. Except this, customers claimed that they are partly satisfied with fuel quality and service. However, yet the focus remain at the fuel excise tax. When addressing such market failure, one common perception of the problem is the price level in a non-regulated market. Thus, the expectations of consumers are to control prices by leading to stable and reasonable costs, which in turn would provide an equally liberal market and the inability to manipulate on behalf of prices. As a result, consumers and transportation companies will be more aware of administrative structures, which will specify all necessary duties and obligations for the price set.

In addition, there are several recommendations related to the nature of the issue, which may be significant in the long-term if correctly applied. Firstly, reducing the level and dispersion of excise tax rate may lead the Kosovar oil market to transfer from unfavorable oil market conditions to satisfied ones. Secondly, the lack of cash registers affects negatively the price reduction. Based on secondary data, a majority of oil companies have refused and resisted state organs not to be equipped with special cash register. For the connoisseurs of this field, this has affected petroleum prices, as the oil producers never declare the exact amount of sales. Thus, cash register is a necessary issue to be applied in the market. Thirdly, price control is essential to create stable and reasonable prices. Actually, price control comes in two flavors: a price floor, a minimum price set by the government and a price ceiling, where the government mandates a maximum allowable price for a good. Such applications will lead to better and enjoyable market condition. However, in Kosovo oil market, Kosovo still find difficulties to have such mechanisms to overcome oil market problems. To tackle down such problems, Kosovo should seek to adapt systems from other countries and resolve the concerns.

\section{References}

Energy Regulatory Office (2015). Statement of Security of Supply for Kosovo (Electricity, Natural Gas and Oil). Statement of Security of Supply for Kosovo (Electricity, Natural Gas and Oil) (n.d.): n. pag. 2015. Web. 28 Feb. 2017.

FocusEconomics (2017). OPEC History: Has It Been a Success? FocusEconomics, Economic Forecasts from the World's Leading Economists, 27 May 2017, www.focus-economics.com/blog/opec-history-hasopec-been-a-success.

Mahapatra, L. (2019). Gas Prices At The Pump: Europeans Pay Almost Twice As Much As US Residents. International Business Times. N.p., 05 Dec. 2015. Web. 29 Mar. 2019.

Oleg, S. (2017). Fuel Price in Europe, Autotraveler.ru. N.p., Jan. 2017. Web. 28 Feb. 2017.

Rose, E. A. (2004). OPEC's Dominance of the Global Oil Market: The Rise of the World's Dependency on Oil. Middle East Journal, 1 July 2004, www.jstor.org/stable/4330033?seq=1\#page_scan_tab_contents

Tota, E. (2017). Kosovo with the Highest Price of Fuel in the Region. Independent Balkan News Agency. N.p., 07 Jan. 2015. Web. 27 Feb. 2017.

\section{Other web sources}

*** Gasoline Prices around the World, 25-Mar-2019. GlobalPetrolPrices.com, 25 Mar. 2019, www.globalpetrolprices.com/gasoline prices/.

*** How Will the Agreement between OPEC Members Be Affecting Kosovo? RIT Kosovo Economists' Club, 13 Dec. 2016, aukonomics.wordpress.com/2016/12/13/how-will-the-agreement-betweenopecmembers-be-affecting-kosovo/.

*** Kosovo - Import TariffsKosovo - Import Tariffs. Kosovo - Import Tariffs, 26 Feb. 2019, www.export.gov/article?id=Kosovo-Import-Tariffs.

*** Kosovo GDP." Kosovo GDP | 2019 | Data | Chart | Calendar | Forecast | News, 2019, tradingeconomics.com/kosovo/gdp.

*** Kosovo Agency of Statistics. International Trade Statistics, December 2018 I, 24 Jan. 2019, ask.rks-gov.net/en/kosovo-agency-of-statistics/add-news/international-trade-statistics-december-2018.

***https://www.iene.eu/articlefiles/outlook17 roec.pdf 